\title{
Re-Imagining Indigenous Education for Health, Wellbeing and Sustainable Development in Remote Australia
}

\author{
Rosalie Schultz' ${ }^{1}$ Tammy Abbott ${ }^{2}$, Jessica Yamaguchi ${ }^{3}$, Sheree Cairney ${ }^{1,4}$ \\ ${ }^{1}$ Centre for Remote Health, Flinders University, Alice Springs, Australia \\ ${ }^{2}$ Community Engagement, Ninti One Ltd, Alice Springs, Australia \\ ${ }^{3}$ Information and Evaluation Branch, Department of the Prime Minister and Cabinet, Canberra, Australia \\ ${ }^{4}$ Interplay Project, Alice Springs, Australia \\ Email: Rosalie.schultz@flinders.edu.au
}

How to cite this paper: Schultz, R., Abbott, T., Yamaguchi, J., \& Cairney, S. (2018). Re-Imagining Indigenous Education for Health, Wellbeing and Sustainable Development in Remote Australia. Creative Education, 9, 2950-2972.

https://doi.org/10.4236/ce.2018.916222

Received: November 28, 2018

Accepted: December 25, 2018

Published: December 28, 2018

Copyright (ㅇ 2018 by authors and Scientific Research Publishing Inc. This work is licensed under the Creative Commons Attribution International License (CC BY 4.0).

http://creativecommons.org/licenses/by/4.0/

\begin{abstract}
In Australia both Indigenous communities and governments are concerned at the educational outcomes of Indigenous children, especially children in remote regions. However, there are divergent visions of Indigenous education. For Indigenous communities, education embraces culture and contributes to wellbeing, the focus of our research, while for governments, educational goals comprise school attendance, English literacy and completion of year 12. Our team of Indigenous and non-Indigenous researchers explored wellbeing for Indigenous people in remote Australia through focus groups and interviews. Grounded analysis showed how research participants would like more Indigenous education for their children. Their vision for education includes transmission of Indigenous knowledge and skills in art, culture, history, land and sea management, and literacy in both English and Indigenous languages. Remote Indigenous communities hold under-utilised resources and strengths for education, and Indigenous people's knowledge is needed, particularly in conservation and land and sea management. Research participants feel thwarted by education policies which require competition for funding and segregation of services. Re-imagining education from the perspectives of Indigenous communities offers opportunities to enhance education, together with employment, health and wellbeing, and strengthen Indigenous languages, knowledge and skills. These are important for both overcoming Indigenous disadvantage and for Australia to reach its commitments to conservation and sustainable development goals.
\end{abstract}

\section{Keywords}

Indigenous People, Education, Wellbeing, Culture, Land Management, Sustainable Development 


\section{Introduction}

Education directly enhances people's agency, capacity, capabilities and wellbeing. Indirectly, education enhances health and wellbeing, through both economic and intangible benefits, such as creativity, tolerance and community cohesion (Vila, 2000). Both the people who are educated, especially children, and their communities benefit from education (Robeyns, 2006). Benefits of education cross generations, highlighting the importance and urgency of improving the effectiveness of Australia's education systems to meet the needs of Indigenous peoples (Partington \& Beresford, 2012).

\subsection{Indigenous Australians}

Indigenous Australians comprise two distinct and diverse populations, Aboriginal and Torres Strait Islander peoples, who together number approximately 700000 people or 3\% of Australians. For brevity we refer to "Indigenous" Australians to include both Aboriginal and Torres Strait Islander peoples.

Indigenous Australians have occupied Australia for 50000 years, and continue to identify themselves as distinct from other Australians, whose arrival since the late 1700 s led to the deaths of $75 \%$ of Indigenous Australians (Australian Institute of Health and Welfare, 2015). Forced removal of Indigenous children from their homelands and families continued until the 1970s through Australia's assimilation and protection policies (Partington \& Beresford, 2012).

Australians voted in a referendum in 1967 for the national government to take responsibility in Indigenous affairs (Partington \& Beresford, 2012). Since then Indigenous Australians have been included in Australia's population census, providing data on education, employment and other indicators. Availability of data has prompted governments and communities to develop policies intended to improve Indigenous indicators (Altman, Biddle, \& Hunter, 2008).

Indigenous Australians established that they had legal right to their lands in the 1992 Mabo court case if they could demonstrate that their pre-colonial system of land tenure, dubbed "native title", still functions (Altman \& Markham, 2015). However native title rights are limited and Indigenous people's economic opportunities and access to appropriate education, health, and infrastructure remain inadequate, especially in remote regions where Indigenous people comprise $30 \%$ of the population (Australian Bureau of Statistics, 2018; O'Faircheallaigh, 2015). Indigenous Australians remain disadvantaged in almost all socioeconomic indicators, and many indicators are lower for people in remote regions.

\subsection{Indigenous Australian Education}

Educational disadvantage for Indigenous children in remote Australia is of widespread concern. Less than $2 / 3$ of Indigenous children in remote regions attend school; less than half reach minimum reading standards at Year 3; and only $42 \%$ complete 12 years of schooling compared with $89 \%$ of all Australian stu- 
dents (Commonwealth of Australia: Department of Prime Minister and Cabinet, 2018). Policy-makers believe that improving these education indicators is necessary to improve people's life experiences (Commonwealth of Australia: Department of Prime Minister and Cabinet, 2018). However aspects of Australia's approach to Indigenous education are based on assumptions that are not supported by evidence, and may undermine the strengths and diversity of Indigenous people (Guenther, 2013).

Education is much more than schooling, especially for Indigenous people, for whom school has arisen in the context of historic and on-going colonization. Attending school has costs, particularly where children face racism in its many forms (Bodkin-Andrews \& Carlson, 2016). Racism at school contributes to the disengagement of Indigenous children and families from school and the education system (Gollan \& Malin, 2012).

\subsection{Education, Health and Wellbeing for Indigenous Australians}

In most populations, education is directly correlated with health. Education improves health throughout people's lives, through psychological and social effects such as self-esteem and confidence, and increasing health literacy (Cohen \& Syme, 2013). Education also improves health through increasing employment opportunities, facilitating access to healthier, safer, more secure and higher status work (Vila \& Garcia-Mora, 2005). The greater economic benefits from skilled and professional employment further increase the health benefits of education (Ross \& Wu, 1995).

However, relationships between education and health are in both directions: better health enhances people's motivation and capacity to learn, while many medical conditions can interfere with learning (Basch, 2011). Hearing impairment is a particular concern for Indigenous Australian children in remote regions where $90 \%$ suffer ear disease (Morris et al., 2005). Hearing impairment causes problems at school for both affected children and their peers. Entire classrooms are disadvantaged when children are disruptive because they cannot hear and communicate effectively (Partington \& Galloway, 2005).

Chronic or recurrent illnesses that lead to frequent absences also affect school performance, an important issue for Indigenous Australian children, in whom many conditions are more common than in non-Indigenous children (Dockett, Perry, \& Kearney, 2010). These include anemia, diarrhea, dental caries, and respiratory, skin and urinary infections (Gracey \& King, 2009). Overall, relationships between children's health and education are complex, with factors such as parental employment affecting both health and education (Lynch \& von Hippel, 2016). However, assumptions from other populations may be confounded in their application to Indigenous Australians (Biddle, 2006).

For Indigenous Australians a U-shaped relationship between education and health has been described, with better health among the people with the lowest and the highest levels of education (Shepherd, Li, \& Zubrick, 2012). This relationship suggests that the interactions between education and health for Indi- 
genous people differ substantially from the consistently positive associations in other populations (Lynch \& von Hippel, 2016). Damaging effects of racism that Indigenous people face at school and work may outweigh possible future benefits of education (Shepherd et al., 2012). Because of incomplete knowledge of relationships between health and education for Indigenous people, current strategies to improve education may not lead to anticipated benefits (Boughton, 2000).

\subsection{Improving Educational Outcomes for Indigenous Australians}

The Australian Government's 2009 Closing the Gap: National Indigenous Reform Agreement aimed to address disparities in socio-economic indicators between Indigenous and non-Indigenous Australians. The Agreement recognized interconnections between education, employment and health, and included targets of reduced disparities between Indigenous and non-Indigenous Australians in each (Council of Australian Governments, 2012). The education targets were to eliminate disparities in school attendance, and halve the disparities in reading, writing and numeracy between Indigenous and non-Indigenous children by 2018; and halve the disparity in year twelve attainment by 2020 . Health targets were to halve the child mortality difference by 2018 and eliminate the difference in life expectancy by 2031 (Commonwealth of Australia: Department of Prime Minister and Cabinet, 2018).

While many Australians support the idea of reducing disparities, both Indigenous and non-Indigenous people have raised concerns with the Closing the Gap strategy. The perceived need for Indigenous Australians to overcome disparity and become more like non-Indigenous people reflects a perception of Indigenous people as problematic, and of non-Indigenous people as providing appropriate targets (Walter, 2016). This approach can overlook the strengths, diversity and different lifeways and aspirations of Indigenous people (Altman, 2009).

Effective approaches to policy development to reduce Indigenous disadvantage require attention to needs defined by Indigenous people and communities themselves.

Wellbeing provides a basis for defining need, and an opportunity for development that is not biased towards any particular culture or section of society (OECD, 2017). Enhancing wellbeing as a development goal enables fair comparison between people of different cultures, within societies and over time (Cairney et al., 2017; OECD, 2017). Indigenous Australians in remote communities report high levels of wellbeing with mean life satisfaction 7.6, equal to the average life satisfaction of all Australians (Australian Bureau of Statistics, 2015, 2016), an overlooked statistic when much policy focus is on changing poor indicators in education, employment and health, violence, crime and imprisonment (Australian Institute of Health and Welfare, 2015). Our research was designed to explore wellbeing for Indigenous people in remote Australia to provide a basis for education and other policy development based on Indigenous people's diverse aspirations and goals. 


\section{Methods}

\subsection{Education as a Wellbeing Priority}

Our research aimed to explore and explain the conundrum of high levels of wellbeing despite low indicators in education, employment and health among Indigenous people in remote Australia, through a framework developed collaboratively with Indigenous researchers and participants. Both Indigenous and non-Indigenous methodologies and knowledge were used, with Indigenous and non-Indigenous people teaching and learning from one another in a two way process (LaFlamme, 2011). We aimed to share knowledge between communities, scientists and government, and ensure community development, rigorous science, and policy impact (Cairney et al., 2017).

Six priorities were identified to form a wellbeing framework: education, employment and health being those of government; and Indigenous people's priorities of community, culture and empowerment.

Indigenous communities throughout remote Australia with connections to the research team were invited to participate. Four communities were selected, with a range of levels of remoteness, and diverse geography, culture and language use, population size and proportion who are Indigenous.

In each community, Indigenous Community Researchers were employed in the research, including facilitating focus groups through Indigenous organizations. Focus groups enable exploration of participants' knowledge and experience, building on other group members' contributions. They are particularly valuable in cross-cultural research, and in enabling criticism of services that individuals may withhold from researchers (Kitzinger, 1995). No-one was excluded from participation, and people who could not participate in focus groups were interviewed individually. Demographics of participants are described in Table 1 and Table 2, with 68 Indigenous and seven non-Indigenous participants in 14 focus groups, and four Indigenous and one non-Indigenous service providers interviewed between June 2014 and June 2015.

Focus groups and interviews were audio-recorded, then transcribed and thematically coded, based on the wellbeing priorities, and on sub-themes which emerged in the discussions.

This article describes findings that relate to education and its relationships with wellbeing for Indigenous people in remote Australia.

\subsection{Ethics}

All Indigenous people and organizations involved actively engaged with the research, providing an Indigenous ethical framework for the research. Formal ethics approval was granted by the Human Research Ethics Committee of the Northern Territory Department of Health and Menzies School of Health Research (Reference 2013-2125) and the Western Australian Aboriginal Health Ethics Committee (HREC Reference Number 549). All participants gave written informed consent. 
Table 1. Research participants in focus groups by service, Indigenous status and gender.

\begin{tabular}{ccccc}
\hline Service & Participants & $\begin{array}{c}\text { Total } \\
\text { participants }\end{array}$ & $\begin{array}{c}\text { Indigenous } \\
\text { participants }\end{array}$ & $\begin{array}{c}\text { Female } \\
\text { participants }\end{array}$ \\
\hline Business development & Managers & 2 & 1 & 0 \\
Education & Managers, employees & 6 & 6 & 6 \\
Education & Managers, employees & 12 & 12 & 9 \\
Land and Sea Management & Community members & 4 & 4 & 3 \\
Land and Sea Management & Employees & 4 & 4 & 1 \\
Land and Sea Management & Employees & 4 & 4 & 4 \\
Land and Sea Management & Employees & 7 & 7 & 0 \\
Land and Sea Management & Employees & 8 & 8 & 8 \\
Health & Managers, employees & 4 & 1 & 1 \\
Health & Employees, community & 9 & 9 & 0 \\
Health & Employees & 3 & 1 & 3 \\
Municipal & Managers, employees & 6 & 6 & 4 \\
Municipal & Managers & 2 & 1 & 1 \\
Research & Employees & 4 & 4 & 4 \\
Total & & 75 & 68 & 44 \\
\hline & & & & 4 \\
\hline
\end{tabular}

Table 2. Interview participants by service, Indigenous status and gender.

\begin{tabular}{ccccc}
\hline Service & Participants & $\begin{array}{c}\text { Total } \\
\text { Interviews }\end{array}$ & $\begin{array}{c}\text { Indigenous } \\
\text { Interviewees }\end{array}$ & $\begin{array}{c}\text { Female } \\
\text { Interviewees }\end{array}$ \\
\hline Art & Manager & 1 & 1 & 1 \\
Business development & Manager & 1 & 1 & 0 \\
Education & Founder & 1 & 1 & 1 \\
Education & Manager & 1 & 1 & 0 \\
Land and sea management & Program leader & 1 & 0 & 1 \\
\hline
\end{tabular}

\section{Results}

\subsection{Education for Meaningful Livelihoods for People in Remote Regions}

Research participants described the need for distinctive Indigenous schooling and education to support Indigenous people to remain on their traditional land with knowledge and skills to engage in contemporary society.

"We grew up here and are the traditional owners. Our elders fought hard for this country to continue on for other generations." (Participant in focus group 9)

"The best learning for our people is on the land." (Interview 4: Indigenous service provider)

"The school's mantra is Indigenous people: strong in both worlds." (Interview 2: non-Indigenous service provider) 
Research participants confirmed that Indigenous families in remote Australia, appreciate and enjoy quality school and education:

"Lots of our kids love school, they love school." (Participant in focus group 4)

\subsection{Improving School Attendance and Educational Participation}

Increased school attendance was a target of the Closing the Gap strategy, but there has been no progress nationally in increasing Indigenous school attendance overall, and attendance in the Northern Territory declined (Commonwealth of Australia: Department of Prime Minister and Cabinet, 2018). In our research, participants identified reasons for children and young people to not attend school. These included children feeling a lack of freedom and connection to the culture of the school, and that they have out-grown school. Non-attendance was then linked to risk-taking behaviors.

"I think it is the freedom, like our people weren't locked up... enclosed in a school getting all of this stuff pumped into us ... We were out on the land and education was cultural, and education was survival and learning to live off the land in our culture and our country... not in the classroom." (Interview 4: Indigenous service provider)

“They obviously don't want to go to school coz they feel like they're too big to go to a school. They don't feel like they little kids going to a school setting. Is there another place they could go to... to learn to continue their learning in [this community]?" (Participant in focus group 4)

"Some kids reach 13 and 14 years old and think they are adults-they start drinking and gunja [marijuana] and take off." (Participant in focus group 4)

In our research, participants identified how communities could respond to children not attending school by listening to community elders and seeking cultural advice.

“The elders say... send kids to school." (Participant in focus group 9)

"Cultural advisors help with any trouble like kids going to school." (Participant in focus group 9)

\subsection{Pathways from Education to Employment}

Although the importance of attending school was recognized, some participants in our research believed that culture is more important than school, and if young people are educated about Indigenous culture, then attending school may be less important.

"If they're old enough to go out, [they should] get away from the community so they learn more cultural stuff. It's an education issue, it's the way learning about the land." (Participant in focus group 1)

For many Indigenous research participants, relationships between education, school and future wellbeing are not closely linked. Research participants stated:

“The kids don't know how to do things after school, they don't know how to look for a job and they are too shame to. They should have a program at the 
schools that prepare them for what they do after. They're not working together after they leave school, they don't prepare them for school leaving. Then they get into drugs and everything." (Participant in focus group 6)

"No pathways-kids leave middle school and don't go onto secondary school." (Participant in focus group 9)

Many employment opportunities in remote communities, such as in art and land and sea management programs arise from Indigenous culture and knowledge. Education to support such employment will enhance Indigenous culture and knowledge, and may be better delivered outside the school environment. Research participants noted:

"[Young people] recognize the employment pathway between education and programs such as the ranger program, so we support school camps for this program." (Participant in focus group 3)

"Workplace accredited training, largely not classroom based. TAFE send out teachers to work on site-culturally appropriate, not as invasive." (Interview 2: non-Indigenous service provider)

Indigenous history and culture are of special interest to Indigenous people and may assist in retaining Indigenous students' interest. Research participants noted the importance of these areas:

"People including our own mob don't know Indigenous history. It's not taught in schools, in training there is nothing on it." (Participant in focus group 10)

"Learning on country program... working with schools. Culture program has always been here, to help them understand the Dhuwa, Yirritja way that's been here since the start." (Participant in focus group 14)

\subsection{Indigenous Knowledge and Expertise}

Indigenous histories and cultures are described in Australia's education curriculum as a cross-curriculum priority, rather than an area of learning, with the intention of improving outcomes for Indigenous students. Learning from, with and about Indigenous Australians is not required in Australian schools (Australian Curriculum Assessment and Reporting Authority (ACARA); Williamson-Kefu, 2016).

Research participants identified how Indigenous knowledge may be valuable for all children in the teaching of art, culture, history, ecology, land and sea management and language. Indigenous education occurs both in the school and when working on the land:

"She walks around the school; shows kids different types of plants and cultural education about the plants." (Participant in focus group 4)

"It gives you an opportunity to learn the stories of the country as well ... when we're out there working, we're learning, we're passing something on to young people." (Participant in focus group 1)

Indigenous people in our research welcomed opportunities to share their knowledge, and contribute to schooling and education through other services. 
"I like learning both ways-white fella way and Martu way. Helping one another-learning from one another-teamwork." (Participant in focus group 1)

"It was hard first, you know. But now the Balanda [non-Indigenous people] here today they've learned a lot of things what we-that we started to respect them, you know and they respect us, also." (Participant in focus group 7)

"The little term is 'Ngapatji, ngapatji' and that means-you come and work with us, we work with you. Two way and that's the rule, you know." (Participant in focus group 7)

\subsubsection{Indigenous Languages}

Indigenous languages were important for Indigenous research participants. Multilingualism is a feature of Indigenous Australian society and connects people to their land, community and family. Indigenous languages are also used as a sign of resistance against colonization and Australia's monolingual Australian government and institutions (Simpson \& Wigglesworth, 2018). Indigenous research participants described the value of Indigenous languages for Indigenous children at school:

"[Indigenous] people want to talk their language because to them, it's like they got their language they speak all the time. Why don't we speak our languages at school, you know, like they want to be recognised?" (Participant in focus group 4)

"Coz our language, they should put our language, that [Indigenous] language, we should be there, coz we're the first nations of the land." (Participant in focus group 4)

\subsubsection{Indigenous Land Management}

Indigenous land management involves Indigenous people using customary knowledge and skills together with modern techniques in managing fire, weeds and feral animals; monitoring and protecting threatened species; inland waterway and coastal surveillance; revegetation; pastoralism; harvesting of bush foods; and art and craft work (Hill et al., 2013). Indigenous land management programs are popular and effective for engaging people in education and employment, as one research participant noted:

"I can't think of another program that has achieved pathway from training into employment like this program has done. There are not any other examples of things happening in this community that have successfully achieved this outcome. This program provides training within the context of the job... There's four of the fellows here, they're doing Certificate 3 in Conservation and Land Management, so the work here links into that." (Interview 1: Non-indigenous Land Management program leader).

\subsection{Intersectoral Partnerships}

Some organizations involved in the focus groups were providing services beyond 
their main role. For example, education services for Indigenous people provide training in land and sea management, and traditional foods and medicines. This supports education, employment and health outcomes. Such collaboration demonstrates commitment to outcomes based on the needs of the Indigenous community:

"My family have been involved with the kids programs. Every school holidays we go out bush. Over the years they [the school kids] have been supported for this program by DCP [Department of Child Protection] and AMS [Indigenous Medical Service]." (Interview 4: Indigenous service provider)

"It is a real partnership, that's the way to engage people and the women's group meetings. Engagement, cooking, talking to people, good approach for social work." (Participant in focus group 5)

These examples highlight service perspectives driven by Indigenous communities rather than government departments.

Research participants highlighted commonalities across services and opportunities to work together for common aims:

"We've had to look at other ways to fund from other avenues and partnerships to pull money in, and taking this on like an enterprise rather than a centrally funded idea." (Interview 2: non-Indigenous service provider)

"Judy [nurse] is doing preventative work with the school kids, if identified for referral to the Medical services through the school." (Participant in focus group 3).

Outcomes that Indigenous communities seek from services may not be those that the services are established to provide; these include care of the community and the land. One research participant stated:

"Government think school and employment are the only priorities. We don't. There's other things." (Participant in focus group 9)

\subsection{Service Models for Indigenous Communities}

Research participants explained how partnerships and relationships can be important outcomes in themselves:

"I was apprehensive because I am not Martu [Indigenous] but Martu are working here helping mentor me in my role, it is a good partnership." (Participant in focus group 5)

In remote communities, separation between departments and bureaucracies leads to lack of coordination and inefficiencies in services, and this especially affects Indigenous people. Focusing on the needs of people and communities, and bringing resources together to meet those needs is likely to achieve better outcomes.

Some rules and formalities appeared counter-productive and absurd for research participants. In remote Indigenous communities, greater flexibility around employment and registration conditions may enhance service delivery and outcomes, and reduce the disparities in service provision. 
"We are trying to argue the case that the school-health partnership should allow the psychologist to work in the school... There are 50 odd kids on a waiting list to see the psychologist but as she cannot see the kids at school, so they are not getting the services." (Participant in focus group 4)

Policies and regulations designed to improve service provision and quality in urban centres may be inappropriate in small communities.

Lack of attention to relationships was quite distressing for one of the interviewees, because for her as an Indigenous person, relationships are central to wellbeing.

"Lack of communication and not working together, too much politics and not working together. Jealously business, it disconnects [Indigenous educational organisation] straight away. Not connected." (Interview 5: Indigenous service provider)

These issues are compounded by competition between service providers for a limited pool of resources. Competition can undermine interpersonal relationships and highlight differences and disagreements among community members and services, particularly when people and services have similar overall aims.

"It all comes back to the same thing, the funding competing for each other. It's all in silos still. If you say interplay between education and health, that's not how it happens on the ground. They're all working separately silos." (Participant in focus group 10)

"Because when funding comes to [Indigenous educational organisation], clinic gets jealous, and school want to do it on their own, and they have ideas about [Indigenous educational organisation] and they don't work with [Indigenous educational organisation].” (Interview 5: Indigenous service provider)

\section{Discussion}

\subsection{Remoteness and Equity}

Australia's remoteness classifications were developed to support equitable service provision, but did not consider what remoteness means for Indigenous Australians (Australian Bureau of Statistics, 2014). For many Indigenous people, their land is their spiritual home, even though this is classified remote and statistically disadvantaged (Birch, 2016; Walker, Porter, \& Marsh, 2012). Indigenous Australians may be the dominant cultural group in remote communities, and less subject to racism (Priest, Paradies, Stewart, \& Luke, 2011). Thus Indigenous people's insights are needed to understand the importance of associations between remoteness and statistical disadvantage. Education for non-Indigenous Australians about remoteness may improve educational outcomes for Indigenous Australians in remote communities.

\subsection{School Attendance}

The goal of increasing Indigenous children's school attendance assumes that their lower attendance contributes directly to their lower educational outcomes 
compared with other children (Commonwealth of Australia: Department of Prime Minister and Cabinet, 2018; Gray \& Partington, 2012). However, the relationship is complex, and social, cultural and economic factors that contribute to Indigenous children's lower rates of school attendance also impact on their educational outcomes. For communities for whom the overall outcomes of school are less important, attendance is less important (Gray \& Partington, 2012).

The importance of school attendance depends on the desired outcomes. Focusing on educational outcomes that meet the needs of Indigenous communities may lead to effective teaching and learning outside the formal school environment (Fogarty \& Schwab, 2012). As research participants highlighted, attending school may not be necessary, and education about Indigenous culture, language and land management may be better provided outside school.

Even where attending school is considered essential, policies that manipulate families through coercion and punishment may have negative effects. Strategies that limit people's autonomy can increase the resistance of both parents and children to attending school (Guenther, 2013). For example, quarantining portions of welfare payments was introduced to Indigenous communities in 2007, with the aim of improving school attendance. Evaluation showed that welfare quarantining led to an initial reduction in school attendance, through increased family stress (Cobb-Clark, Kettlewell, Schurer, \& Silburn, 2017).

Effective approaches to increasing school attendance take account of the reasons why children do not attend school. In our research, reasons for children not attending school were loss of freedom, removal from culture, and the disconnection from future livelihoods on the land. Addressing these issues through curriculum development may assist in improving educational outcomes, regardless of school attendance.

Research participants recognized the importance of school and education. They described how involving elders and cultural education could assist in retaining adolescents at school.

\subsection{Indigenous Culture, Health, Knowledge and Land Management}

Research participants identified cultural, knowledge and infrastructure resources in their communities which could improve Indigenous education, and these are summarized in Table 3.

Indigenous child-rearing skills and practices can contribute to Indigenous education. Indigenous parents emphasize promoting children's freedom to explore and experience the world, which increases their independence and creativity (Lohoar, Butera, \& Kennedy, 2014). These are strengths of Indigenous communities and can assist in education, and promote learning both within and outside school.

Indigenous people's knowledge could improve the response to ear disease, which harms schooling of all children. Australia's national guideline for ear disease focusses on clinical definitions, treatments and outcomes, and recommends 
Table 3. Strengths and resources to inform development of meaningful indicators of Indigenous education in remote Australia.

\begin{tabular}{|c|c|c|}
\hline \multicolumn{3}{|c|}{ Source of strengths and resources } \\
\hline Student & School & Community \\
\hline Creativity & $\begin{array}{l}\text { Transmission of } \\
\text { traditional knowledge }\end{array}$ & Elders and cultural advisors \\
\hline Eagerness to learn & Learning on country & $\begin{array}{l}\text { Indigenous knowledge: ecological } \\
\text { knowledge, language, history }\end{array}$ \\
\hline \multirow[t]{4}{*}{ Independence } & Community-based schools & $\begin{array}{l}\text { Family desire to support } \\
\text { children at school }\end{array}$ \\
\hline & Two-way learning & $\begin{array}{l}\text { Partnerships and collaborations } \\
\text { between organisations and services }\end{array}$ \\
\hline & $\begin{array}{l}\text { Workplace based } \\
\text { training and assessment }\end{array}$ & $\begin{array}{l}\text { Pathways from education to employment } \\
\text { such as through Ranger programs }\end{array}$ \\
\hline & & Building infrastructure \\
\hline
\end{tabular}

that parents be advised to recognize the problem of ear disease and act quickly if the child has symptoms (Morris et al., 2015). Indigenous community responses to children's ear disease, based on Indigenous sign languages and non-hearing communication appear under-recognized (Lowell, 2013), as is the experience of learning Indigenous cultural knowledge, where communication difficulties related to hearing impairment do not seem to be a barrier (Fogarty \& Schwab, 2012).

Australia's 1989 National Aboriginal Health Strategy and each of its iterations have pointed to the wellbeing of Indigenous Australians, their community and land as being central to Indigenous health (Australian Government, 2013; National Aboriginal Health Strategy Working Group, 1989). However the wellbeing of Australia's lands and seas are deteriorating and current conservation strategies are inadequate (Cresswell \& Murphy, 2016). Environmental degradation directly contributes to the health status of Indigenous people. For example, in the state of New South Wales Indigenous people affected by drought associated with human induced climate change are suffering mental health problems and social and economic losses (Rigby, Rosen, Berry, \& Hart, 2011), while Indigenous people in urban Victoria reported that degradation of ecosystems contributes to their sicknesses (Kingsley, Townsend, Phillips, \& Aldous, 2009).

Over millennia, Indigenous people's management of lands and seas has contributed to the development of Australia's ecosystems. The removal of Indigenous people from their lands and cessation of Indigenous land management practices are contributing to the deterioration of ecosystems and loss of biodiversity (Cresswell \& Murphy, 2016). The importance of Indigenous ecological knowledge is increasingly being recognized in Australia's conservation strategies. Indigenous knowledge and skills contribute to research and management of feral animals and weeds, protection of coasts, waterways and other ecosystems, fire management leading to increased carbon storage with potential for large scale 
carbon farming, and conservation of biodiversity and ecosystems (Cresswell \& Murphy, 2016; Hill et al., 2013).

Recognition of the role of Indigenous people in conservation and land management has led to the establishment of Indigenous Protected Areas (IPAs) where Indigenous people are given responsibility for managing their traditional lands and seas, in accordance with Australia's commitments to international organizations such as the International Union for the Conservation of Nature (IUCN). IPAs now comprise almost half of Australia's nature reserves (Cresswell \& Murphy, 2016) so Indigenous people with land management knowledge and skills are needed for Australia to meet international conservation commitments (Commonwealth of Australia, 2011; Fogarty, 2012). Including Indigenous knowledge in education curricula as highlighted in our research will be essential for this to continue. Since Indigenous knowledge has not been consistently transmitted to younger people, Indigenous people are concerned at the loss of their knowledge which is not yet included in the curriculum (Douglas, 2011).

Indigenous people's health depends on the health of the land, so health and land management services could be managed cooperatively (Kingsley et al., 2009). Working in land management improves the health of Indigenous people, including increased levels of physical activity, improved diet, less obesity and diabetes and renal disease, lower blood pressure, blood sugar and cholesterol, and cardiovascular disease risk (Burgess et al., 2009). These indicators support Indigenous people's holistic understanding of their own and their country's health, where caring for the country is caring for oneself and one's family. Indigenous individuals' health is associated with wellbeing of community and country, and with using Indigenous languages (Biddle \& Swee, 2012).

Indigenous culture, knowledge and languages are important areas of Indigenous expertise, which provide opportunities for two-way learning between Indigenous communities and service providers (McRae et al., 2000). Indigenous languages are embedded in the land, and enable Indigenous people to articulate their unique knowledge. Current Australian schooling in English is likely to be contributing to loss of Indigenous languages and irretrievable loss of Indigenous knowledge (Nettle \& Romaine, 2000). Australian education authorities are ambivalent about Indigenous languages, with for example Northern Territory bilingual programs cut in 1998, then terminated in 2008 in response to media representation of the crises in Indigenous education (Nicholls, 2005; Waller, 2012). Meanwhile there is global concern at the loss of indigenous languages and the impact of this on cultural survival (United Nations Economic and Social Council, 2016). The concerns of Indigenous research participants with using, maintaining and strengthening their languages at school reflect a global recognition of the irreplaceable value of indigenous languages as part of human heritage (Nettle \& Romaine, 2000).

\subsection{Service Partnerships, Coordination and Collaboration}

Research participants described how cooperation among services enables com- 
munities to achieve more with limited resources. Different organizations and services have related aims, and partnerships can involve pooling and sharing of resources. Re-imagining education for the needs of Indigenous people could involve changing funding allocation. Rather than services competing for resources, funding that promotes collaboration among service providers may improve relationships, processes and outcomes across sectors in remote communities. Facilitating collaboration between services in remote communities, such as education and health, could improve outcomes in each. For example, education provided by Indigenous health workers in schools could be included in employment structures. This may contribute to overcoming conflicting expectations, racism and stress, which may contribute to the poorer health outcomes among the Indigenous people who reach higher levels of education (Shepherd et al., 2012).

Opportunities for employment in Indigenous land management provide levers for enhancing overall educational outcomes, including Indigenous and English language literacy (Fogarty, 2012). Rather than removing people from mainstream economic opportunities, providing culturally driven education and employment increases Indigenous people's employment participation rates. The National Aboriginal and Torres Strait Islander Social Survey showed that strong traditional culture is associated with improved socio-economic outcomes, as measured and valued by mainstream society (Cairney et al., 2017; Dockery, 2012).

While the terminology of the Closing the Gap Strategy suggests reducing inequity, current efforts to reduce disparities between Indigenous and other Australians involve employing increasing numbers of non-Indigenous people to provide services for Indigenous people (Moran, 2009). Participants in our research reported non-Indigenous service providers in their communities receiving disproportionately high remuneration packages 'as high as the Prime Minister.' (Participant in focus group 10). Salaries of AUD $\$ 380000$ [USD 280 000] in addition to accommodation and other entitlements are offered for remote general practitioners (Rural Health West, 2017). This remuneration is are offered despite lack of evidence of improved recruitment or retention (Buykx, Humphreys, Wakerman, \& Pashen, 2010). Meanwhile overcrowding and associated health and social problems contribute to the disadvantage of Indigenous people, especially in remote regions (SCRGSP, 2016).

The stated commitment to reducing disparity between Indigenous and nonIndigenous Australians is inconsistent with high levels of remuneration for non-Indigenous service providers in remote regions where more than half of Indigenous households live in income poverty (Markham \& Biddle, 2018). Difficulties in recruiting service providers in remote regions, despite high entitlements, draw into question whether there is commitment to reduce the disadvantage of Indigenous people. Commitment to improved wellbeing for Indigenous people could be demonstrated by more equitable social payments in remote communities. For example, subsidizing food supply or improving housing would provide community-wide benefit and enhance equity with service providers (Colles, Maypilama, \& Brimblecombe, 2014; Moran et al., 2016). Classifi- 
cations of remoteness defined to enhance equity in service provision have the perverse outcome of increasing the entitlements for services providers but not social payments to Indigenous people. This increases the disparity between Indigenous and non-Indigenous people in remote regions.

\subsection{Education and Indigenous Knowledge outside Remote Australia}

Our research explored wellbeing with Indigenous people in remote communities and identified education as a priority. Opportunities and strategies to re-imagine education to promote wellbeing require appreciating the aspirations of Indigenous people in remote communities, and recognizing the importance of Indigenous expertise in languages, and land and sea management. Indigenous people's contribution to education can support economic development in remote regions, and improve equity between service providers and Indigenous community members. These strategies for re-imagining Indigenous education in remote communities are summarized in Table 4.

Beyond remote communities, themes of Indigenous identity, culture, empowerment, and employment aspirations are important for Indigenous people throughout Australia (Grieves, 2007; Hunt, 2012). There is scope for expansion of Indigenous land management programs, as Indigenous people in urban areas are eager to establish Indigenous land management practices, based on the success of land management remote Australia (Williamson, 2017). Valuing Indigenous knowledge and skills, and recognizing Indigenous people's goals and aspirations may enhance Indigenous education and wellbeing, and promote Australia's sustainable development.

Australia is committed to the United Nations 17 Sustainable Development Goals (SDGs). These include goals of sustainable use of land and ocean ecosystems, sustainable food production, responding to environmental changes, and building partnerships (United Nations, 2015). Australia's report on progress towards meeting these goals confirms the roles of Indigenous people in meeting these goals (Department of Foreign Affairs and Trade, 2018). Re-imagining Indigenous education will enable Indigenous people to contribute knowledge and skills to Australia's efforts towards the SDGs.

Table 4. Strategies re-imagining Indigenous education in remote communities.

Appreciate remoteness
Value Indigenous aspirations and worldviews
Build collaboration and partnerships
Consider equity between service providers and community members
Strengthen Indigenous knowledge of land and sea management
Strengthen Indigenous languages including sign languages
Support Indigenous people's livelihoods in land management
Reflect Indigenous perspectives on health and wellbeing


Around the world, there is increasing recognition of indigenous peoples' expertise in sustainability (Parsons, Nalau, \& Fisher, 2017). Indigenous people have knowledge and skills in sustainable practices and management of natural resources, shared custodianship of land, and adaptability to and knowledge of climate change (Ens et al., 2015). Many indigenous cultures including many Indigenous people in Australia aspire to buen vivir, "living well" as a goal for human development (Gudynas, 2011). Living well as a policy goal, rather than economic growth, provides a radically different approach to development. Many issues highlighted in our research allude to such an approach: interdependent relationships rather competition; equality and complementarity rather than personal gain; autonomy and identity as outcomes of education. Internationally, many indigenous communities emphasize the importance of family and community in ensuring transmission of indigenous knowledge, to complement formal schooling (Magni, 2017).

Thus greater awareness of Indigenous people and their aspirations in Australia's overall economy may provide a sound basis for development and assist in reaching commitments to global sustainable development agenda (Magni, 2017).

\section{Conclusions}

Positive voices for Indigenous education and wellbeing in Australia's remote communities show diverse benefits and opportunities from engaging with Indigenous people's knowledge and skills in education. Indigenous knowledge of art, culture, history, languages and land management has a key role in the future wellbeing of Indigenous children and in Australia's conservation and land management strategies.

Application of these findings requires action across sectors and levels of Australia's education and land management systems. Greater recognition and use of Indigenous knowledge in the education curriculum would increase understanding of Indigenous culture and languages, and promote capacity for land and sea management. This would assist in ensuring that education in Australia offers meaningful options for Indigenous children to improve attendance and literacy outcomes that are of widespread concern. Developing educational indicators based on Indigenous aspirations will drive policy with benefits for Indigenous people and communities, and Australia as a whole. To attain the Sustainable Development Goals requires Australia to recognize Indigenous knowledge and skills, and adopt approaches to development that meet broader wellbeing goals than economic growth.

\section{Acknowledgements}

This research was supported by funding from the Australian Government Cooperative Research Centre Program through the Cooperative Research Centre for Remote Economic Participation (CRC-REP, hosted by Ninti One Limited).

We acknowledge the support and involvement of key organizational stake- 
holders: Department of Prime Minister and Cabinet, Australian Bureau of Statistics, Centre for Remote Health (Flinders University and Charles Darwin University), Flinders NT - Katherine, Poche Centre for Indigenous Health and Wellbeing - Northern Territory, Banatjarl Strongbala Wumin Grup, Central Desert Native Title Services, Dhimurru Aboriginal Corporation, Kalano Community Association, Katherine Stolen Generations Group, Layhnapuy Homelands Aboriginal Corporation, Marthakal Homelands Resource Centre, Martu Rangers (Wiluna), Miwatj Health Aboriginal Corporation, Muntjiltjarra Wurrgumu Group, Ngangganawili Aboriginal Health Service Community, Northern Star Resources, StrongBala Men's Health Program, Wurli-Wurlinjang Health Service, Yalu Marngithinyaraw Aboriginal Corporation, and Yolngu Business Enterprises.

Ms. Jessica Yamaguchi is an Advisor working for the Australian Government. The views and opinions expressed in this paper are those of the authors and do not reflect the views of the Department of the Prime Minister and Cabinet, the Australian Government and or any State or Territory Governments.

Dr. Rosalie Schultz is supported by a Vincent Fairfax Family Foundation Research entry scholarship, awarded through the Royal Australasian College of Physicians.

\section{Conflicts of Interest}

The authors declare no conflicts of interest regarding the publication of this paper.

\section{References}

Altman, J. (2009). Beyond Closing the Gap: Valuing diversity in Indigenous Australia, CAEPR Working Paper No. 54/2009. http://caepr.anu.edu.au/sites/default/files/Publications/WP/CAEPRWP54.pdf

Altman, J., \& Markham, F. (2015). Burgeoning Indigenous Land Ownership. In S. Brennan, M. Davis, B. Edgeworth, \& L. Terril (Eds.), Native Title from Mabo to Akiba: A Vehicle for Change and Empowerment? Sydney: Federation Press.

Altman, J., Biddle, N., \& Hunter, B. H. (2008). How Realistic Are the Prospects for "Closing the Gaps" in Socioeconomic Outcomes for Indigenous Australians? CAEPR Discussion Paper No 287/2008.

http://caepr.cass.anu.edu.au/research/publications/how-realistic-are-prospects-closinggaps-socioeconomic-outcomes-indigenous

Australian Bureau of Statistics (2014). The Australian Statistical Geography Standard (ASGS) Remoteness Structure. http://www.abs.gov.au/websitedbs/d3310114.nsf/home/remoteness+structure

Australian Bureau of Statistics (2015). 4159.0 - General Social Survey: Summary Results, Australia, 2014. http://www.abs.gov.au/ausstats/abs@.nsf/mf/4159.0

Australian Bureau of Statistics (2016). 4714.0 - National Aboriginal and Torres Strait Islander Social Survey, 2014-15. http://www.abs.gov.au/AUSSTATS/abs@.nsf/exnote/4714.0

Australian Bureau of Statistics (2018). 3238.0.55.001 - Estimates of Aboriginal and Torres Strait Islander Australians, June 2016. 
http://www.abs.gov.au/AUSSTATS/abs@.nsf/Lookup/3238.0.55.001Main+Features1Ju ne\%202016?OpenDocument\#

Australian Curriculum Assessment and Reporting Authority (ACARA). Aboriginal and Torres Strait Islander Histories and Cultures.

https://www.australiancurriculum.edu.au/f-10-curriculum/cross-curriculum-priorities/ aboriginal-and-torres-strait-islander-histories-and-cultures/

Australian Government (2013). National Aboriginal and Torres Strait Islander Health Plan 2013-2023. http://www.health.gov.au/natsihp

Australian Institute of Health and Welfare (2015). The Health and Welfare of Australia's Aboriginal and Torres Strait Islander peoples 2015. Cat. No. IHW 147.

https://www.aihw.gov.au/reports/indigenous-health-welfare/indigenous-health-welfare -2015/contents/table-of-contents

Basch, C. (2011). Healthier Students Are Better Learners: A Missing Link in School Reforms to Close the Achievement Gap. Journal of School Health, 81, 593-598. https://doi.org/10.1111/j.1746-1561.2011.00632.x

Biddle, N. (2006). The Association between Health and Education in Australia: Indigenous/Non-Indigenous Comparisons. Economic and Labour Relations Review, 17, 107-142. https://doi.org/10.1177/103530460601700105

Biddle, N., \& Swee, H. (2012). The Relationship between Wellbeing and Indigenous Land, Language and Culture in Australia. Australian Geographer, 43, 215-232. https://doi.org/10.1080/00049182.2012.706201

Birch, T. (2016). Climate Change, Mining and Traditional Indigenous Knowledge in Australia. Social Inclusion, 4, 92-101. https://doi.org/10.17645/si.v4i1.442

Bodkin-Andrews, G., \& Carlson, B. (2016). The Legacy of Racism and Indigenous Australian Identity within Education. Race Ethnicity and Education, 19, 784-807.

https://doi.org/10.1080/13613324.2014.969224

Boughton, B. (2000). What Is the Connection between Aboriginal Education and Aboriginal Health? https://www.lowitja.org.au/sites/default/files/docs/What_is_the_Connection.pdf

Burgess, C. P., Johnston, F. H., Berry, H. L., McDonnell, J., Yibarbuk, D., Gunabarra, C., Bailie, R. S. et al. (2009). Healthy Country, Healthy People: The Relationship between Indigenous Health Status and "Caring for Country". Medical Journal of Australia, 109, 567-572.

Buykx, P., Humphreys, J., Wakerman, J., \& Pashen, D. (2010). Systematic Review of Effective Retention Incentives for Health Workers in Rural and Remote Areas: Towards Evidence-Based Policy. Australian Journal of Rural Health, 18, 102-109. https://doi.org/10.1111/j.1440-1584.2010.01139.x

Cairney, S., Abbott, T., Quinn, S., Yamaguchi, J., Wilson, B., \& Wakerman, J. (2017). Interplay Wellbeing Framework: A Collaborative Methodology "Bringing Together Stories and Numbers" to Quantify Aboriginal Cultural Values in Remote Australia. International Journal for Equity in Health, 16, 68 .

Cobb-Clark, D. A., Kettlewell, N., Schurer, S., \& Silburn, S. (2017). The Effect of Quarantining Welfare on School Attendance in Indigenous Communities. Life Course Centre Working Paper Series.

https://www.lifecoursecentre.org.au/wp-content/uploads/2018/06/2017-22-LCC-Worki ng-Paper-Cobb-Clark-et-al..pdf

Cohen, A. K., \& Syme, S. L. (2013). Education: A Missed Opportunity for Public Health Intervention. American Journal of Public Health, 103, 997-1001. 
https://doi.org/10.2105/AJPH.2012.300993

Colles, S. L., Maypilama, E., \& Brimblecombe, J. (2014). Food, Food Choice and Nutrition Promotion in a Remote Australian Aboriginal Community. Australian Journal of Primary Health, 20, 365-372. https://doi.org/10.1071/PY14033

Commonwealth of Australia (2011). The Auditor General Audit Report No. 14: 2011-12 Performance Audit: Indigenous Protected Areas.

https://www.anao.gov.au/work/performance-audit/indigenous-protected-areas

Commonwealth of Australia: Department of Prime Minister and Cabinet (2018). Closing the Gap: Prime Minister's Report 2018.

https://www.pmc.gov.au/indigenous-affairs/closing-gap

Council of Australian Governments (2012). National Indigenous Reform Agreement (Closing the Gap).

http://www.federalfinancialrelations.gov.au/content/npa/health/_archive/indigenous-r eform/national-agreement_sept_12.pdf

Cresswell, I., \& Murphy, H. (2016). Australia: State of the Environment 2016: Biodiversity, Independent Report to the Australian Government Minister for the Environment and Energy. https://soe.environment.gov.au/

Department of Foreign Affairs and Trade (2018). Report on the Implementation of the Sustainable Development Goals 2018.

http://dfat.gov.au/aid/topics/development-issues/2030-agenda/Pages/sustainable-devel opment-goals.aspx

Dockery, A. M. (2012). Do Traditional Culture and the Wellbeing of Indigenous Australians? Evidence from the 2008 NATSISS.

http://press-files.anu.edu.au/downloads/press/p206931/pdf/ch131.pdf

Dockett, S., Perry, B., \& Kearney, E. (2010). School Readiness: What Does It Mean for Indigenous Children, Families, Schools and Communities?

https://www.aihw.gov.au/reports/indigenous-australians/school-readiness-what-does-i t-mean-for-indigenous/contents/table-of-contents

Douglas, J. (2011). Learning from Country: The Value of Country Visits in Remote Schools for Community Engagement and Natural and Cultural Resource Management. DKCRC Report 69.

http://www.nintione.com.au/resource/NintiOneResearchReport_69_Thevalueofcountr yvisitsinremoteschools.pdf

Ens, E., Pert, P., Clarke, P., Budden, M., Clubb, L., Doran, B., Wason, S. et al. (2015). Indigenous Biocultural Knowledge in Ecosystem Science and Management: Review and Insight from Australia. Biological Conservation, 181, 133-149.

https://doi.org/10.1016/j.biocon.2014.11.008

Fogarty, B. (2012). Country as Classroom. In J. Altman, \& S. Kerins (Eds.), People on Country: Vital Landscapes, Indigenous Futures (pp. 82-93). Sydney: Federation Press.

Fogarty, B., \& Schwab, R. G. (2012). Indigenous Education: Experiential Learning and Learning through Country. CAEPR Working Paper No. 80/2012.

Gollan, S., \& Malin, M. (2012). Teachers and Families Working Together to Build Stronger Futures for Our Children in Schools. In Q. Beresford, G. Partington, \& G. Gower (Eds.), Reform and Resistance in Aboriginal Education (pp. 149-173). Crawley, WA: UWA Press.

Gracey, M., \& King, M. (2009). Indigenous Health Part 1: Determinants and Disease Patterns. The Lancet, 374, 65-74. https://doi.org/10.1016/S0140-6736(09)60914-4

Gray, J., \& Partington, G. (2012). Attendance and Non-Attendance at School. In Q. Be- 
resford, G. Partington, \& G. Gower (Eds.), Reform and Resistance in Aboriginal Education: Fully Revised Edition (pp. 261-304). Crawley, WA: UWA Press.

Grieves, V. (2007). Indigenous Wellbeing: A Framework for Governments' Aboriginal Cultural Heritage Activities.

http://www.environment.nsw.gov.au/resources/cultureheritage/GrievesReport2006.pdf

Gudynas, E. (2011). Buen Vivir: Today's Tomorrow. Development and Change, 54, 441-447.

Guenther, J. (2013). Are We Making Education Count in Remote Australian Communities or Just Counting on Education? Australian Journal of Indigenous Education, 42, 157-170. https://doi.org/10.1017/jie.2013.23

Hill, R., Pert, P. L., Davies, J., Robinson, C. J., Walsh, F., \& Falco-Mammone, F. (2013). Indigenous Land Management in Australia: Extent, Scope, Diversity, Barriers and Success Factors. Building Resilient Australian Biodiversity Assets Theme.

http://www.agriculture.gov.au/SiteCollectionDocuments/natural-resources/landcare/su bmissions/ilm-report.pdf

Hunt, J. (2012). North to South? In J. Altman, \& S. Kerins (Eds.), People on Country: Vital Landscapes Indigenous Futures (pp. 94-118). Leichhardt: Federation Press.

Kingsley, J., Townsend, M., Phillips, R., \& Aldous, D. (2009). "If the Land Is Healthy ... It Makes the People Healthy": The Relationship between Caring for Country and Health for the Yorta Yorta Nation, Boonwurrung and Bangerang Tribes. Health \& Place, 15, 291-299. https://doi.org/10.1016/j.healthplace.2008.05.009

Kitzinger, J. (1995). Qualitative Research: Introducing Focus Groups. British Medical Journal, 311, 299-302. https://doi.org/10.1136/bmj.311.7000.299

LaFlamme, M. (2011). Learning Journeys: Seven Steps to Stronger Remote Communities. Desert Knowledge CDC Report Number 77.

http://www.nintione.com.au/resource/NintiOneResearchReport_77_LearningJourneys SevenStepstoStrongerRemoteCommunities.pdf

Lohoar, S., Butera, N., \& Kennedy, E. (2014). Strengths of Australian Aboriginal Cultural Practices in Family Life and Child Rearing. CFCA Paper No. 25.

https://aifs.gov.au/cfca/publications/strengths-australian-aboriginal-cultural-practicesfam

Lowell, A. (2013). "From Your Own Thinking You Can’t Help Us": Intercultural Collaboration to Address Inequities in Services for Indigenous Australians in Response to the World Report on Disability. International Journal of Speech-Language Pathology, 15, 101-105. https://doi.org/10.3109/17549507.2012.725770

Lynch, J. L., \& von Hippel, P. T. (2016). An Education Gradient in Health, a Health Gradient in Education, or a Confounded Gradient in Both? Social Science \& Medicine, 154, 18-27. https://doi.org/10.1016/j.socscimed.2016.02.029

Magni, G. (2017). Indigenous Knowledge and Implications for the Sustainable Development Agenda. European Journal of Education, 52, 437-447.

https://doi.org/10.1111/ejed.12238

Markham, F., \& Biddle, N. (2018). Income, Poverty and Inequality. http://caepr.cass.anu.edu.au/sites/default/files/docs/CAEPR_Census_Paper_2.pdf

McRae, D., Ainsworth, G., Cumming, J., Hughes, P., Mackay, T., Price, K., Zbar, V. et al. (2000). What Works? Explorations in Improving Outcomes for Indigenous Students. A Report Prepared for the Commonwealth Department of Education, Training and Youth Affairs by the IESIP SRP National Coordination and Evaluation Team.

https://ncis.anu.edu.au/_lib/doc/visitors/what_works_2000.pdf 
Moran, M. (2009). Demand Responsive Services: Towards an Analytical Framework for Administrative Practice in Indigenous Settlements. Australian Journal of Public Administration, 67, 186-199. https://doi.org/10.1111/j.1467-8500.2008.00581.x

Moran, M., Memmot, P., Nash, D., Birdsall-Jones, C., Fantin, S., Philips, R., \& Habibis, D. (2016). Indigenous Life Worlds, Conditionality and Housing Outcomes. AHURI Final Report No. 260.

http://www.ahuri.edu.au/_data/assets/pdf_file/0016/7315/AHURI_Final_Report_No2 60_Indigenous-lifeworlds,-conditionality-and-housing-outcomes.pdf

Morris, P., Leach, A. J., Silberberg, P., Mellon, G., Wilson, C., Hamilton, E., \& Beissbarth, J. (2005). Otitis Media in Young Aboriginal Children from Remote Communities in Northern and Central Australia: A Cross-Sectional Survey. BMC Pediatrics, 5, 27. https://doi.org/10.1186/1471-2431-5-27

Morris, P., Leach, A., Shah, P., Nelson, S., Anand, A., Daby, J., Patel, H. et al. (2015). The Recommendations for Clinical Care Guidelines on the Management of Otitis Media.

National Aboriginal Health Strategy Working Group (1989). National Aboriginal Health Strategy.

Nettle, D., \& Romaine, S. (2000). Lost Words/Lost Worlds. In Vanishing Voices: The EXtinction of the World's Languages (pp. 94-137). Oxford: Oxford University Press.

Nicholls, C. (2005). Death by a Thousand Cuts: Indigenous Language Bilingual Education Programmes in the Northern Territory of Australia, 1972-1998. International Journal of Bilingual Education and Bilingualism, 8, 160-177. https://doi.org/10.1080/13670050508668604

O'Faircheallaigh, C. (2015). Native Title, Aboriginal Self-Government and Economic Participation. In S. Brennan, M. Davis, B. Edgeworth, \& L. Terril (Eds.), Native Title from Mabo to Akibo: A Vehicle for Change and Empowerment (pp. 158-170). Sydney: Federation Press.

OECD (2017). How's Life? 2017: Measuring Wellbeing. Paris: OECD Publishing. https://doi.org/10.1787/how_life-2017-en

Parsons, M., Nalau, J., \& Fisher, K. (2017). Alternative Perspectives on Sustainability: Indigenous Knowledge and Methodologies. Challenges in Sustainability, 5, 7-14. https://doi.org/10.12924/cis2017.05010007

Partington, G., \& Beresford, Q. (2012). The Context of Aboriginal Education. In Q. Beresford, G. Partington, \& G. Gower (Eds.), Reform and Resistance in Aboriginal Education (pp. 35-85). Crawley: UWA Press.

Partington, G., \& Galloway, A. (2005). Effective Practicies in Teaching Indigenous Students with Conductive Hearing Loss. Childhood Education, 82, 101-106. https://doi.org/10.1080/00094056.2006.10521357

Priest, N., Paradies, Y., Stewart, P., \& Luke, J. (2011). Racism and Health among Urban Aboriginal Young People. BMC Public Health, 11, 568. https://doi.org/10.1186/1471-2458-11-568

Rigby, C. W., Rosen, A., Berry, H. L., \& Hart, C. R. (2011). If the Land's Sick, We're Sick: The Impact of Prolonged Drought on the Social and Emotional Well-Being of Aboriginal Communities in Rural New South Wales. Australian Journal of Rural Health, 19, 249-254. https://doi.org/10.1111/j.1440-1584.2011.01223.x

Robeyns, I. (2006). Three Models of Education: Rights, Capabilities and Human Capital. Theory and Research in Education, 4, 69-84.

Ross, C. E., \& Wu, C.-L. (1995). The Links between Education and Health. American Sociological Review, 60, 719-745. https://doi.org/10.2307/2096319 
Rural Health West (2017). Rural Vacancies: Pilbara-South Hedland-Vacancy Number 1282. Find Your Ideal Healthcare Job in WA.

http://www.ruralhealthwest.com.au/general-practice/recruitment/vacancies\#gp

SCRGSP (2016). Overcoming Indigenous Disadvantage: Key Indicators 2016. http://www.pc.gov.au/research/ongoing/overcoming-indigenous-disadvantage/2016/re port-documents/oid-2016-overcoming-indigenous-disadvantage-key-indicators-2016-r eport.pdf

Shepherd, C. C., Li, J., \& Zubrick, S. R. (2012). Social Gradients in the Health of Indigenous Australians. American Journal of Public Health, 102, 107-117.

Simpson, J., \& Wigglesworth, G. (2018). Language Diversity in Indigenous Australia in the 21st Century. Current Issues in Language Planning.

United Nations (2015). Transforming Our World: The 2030 Agenda for Sustainable Development: $A / R E S / 70 / / 1$.

https://sustainabledevelopment.un.org/post2015/transformingourworld/publication

United Nations Economic and Social Council (2016). Expert Group Meeting on the Theme "Indigenous Languages: Preservation and Revitalization (Articles 13, 14 and 16 of the United Nations Declaration on the Rights of Indigenous Peoples)".

https://undocs.org/E/C.19/2016/10

Vila, L. E. (2000). The Non-Monetary Benefits of Education. European Journal of Education, 35, 21-32.

Vila, L. E., \& Garcia-Mora, B. (2005). Education and the Determinants of Job Satisfaction. Education Economics, 13, 409-425.

Walker, B. W., Porter, D. J., \& Marsh, I. (2012). Fixing the Hole in Australia's Heartland: How Government Needs to Work in Remote Australia.

https://eprints.utas.edu.au/15065/1/Fixing_the_hole_in_Australia\%27s_Heartland.pdf

Waller, L. J. (2012). Bilingual Education and the Language of News. Australian Journal of Linguistics, 32, 459-472.

Walter, M. (2016). Data Politics and Indigenous Representation in Australian Statistics. In T. Kukutai, \& J. Taylor (Eds.), Indigenous Data Sovereignty: Towards an Agenda (pp. 79-108). Canberra: ANU Press, the Australian National University.

Williamson, B. (2017). Reigniting Cultural Burning in South-Eastern Australia: The ACT Aboriginal Cultural Fire Initiative. Native Title Newsletter, 2, 18-20.

Williamson-Kefu, M. (2016). Enhancing the Role of Indigenous Studies in the Australian Curriculum. Journal of Australian Indigenous Issues, 19, 252-265. 